\section{Plant and Fruit Characteristics of a Novel White Nectarine Type}

\author{
Murat Seker, ${ }^{1,2}$ Kenan Kaynas, ${ }^{1}$ Ahmet Yilmaz, ${ }^{1}$ and Uygar Us ${ }^{1}$ \\ Department of Horticulture, Faculty of Agriculture, University of Canakkale \\ Onsekiz Mart, 17020, Canakkale, Turkey
}

Additional index words. Prunus persica, native population, pomology, isozyme, variation

\begin{abstract}
In this study, we described some tree and fruit characteristics of a novel white nectarine type. The genetic diversity within this white nectarine population was investigated using six enzyme systems and its isozyme variation was also compared with common peach and nectarine cultivars. The results demonstrated that there was a significant variation within the white nectarine population in terms of plant and fruit characteristics probably due to the repropagation of the white nectarines using seedlings by growers. This variation was also verified by isozyme polymorphisms. Plants characteristics of white nectarines were similar to the trees of common peach or nectarine cultivars. However, the white nectarines produce less yield than the common peach or nectarine cultivars and they have small fruit with white-cream color and small flesh ratio making their fruit less attractive. We believe that the white nectarines have high market value and consumer acceptance because of its unique flavor which was confused with taste of either plums or apricots. So far, no standard white nectarine cultivar has been reported. This is the first report characterizing some plant and fruit characteristics of white nectarines which could be used for breeding of standard white nectarine cultivars with high yield and fruit characteristics while keeping its unique flavor. In addition, the white nectarines represent a novel source of germplasm for improvement of peaches and nectarines.
\end{abstract}

Peach (Prunus persica (L.) Batsch) is a common fruit species in temperate regions of the world. Three varieties of $P$. persica have been recognized taxonomically based on fruit morphology: the common peach ( $P$. persica var. vulgaris Maxim.) with round and fuzzy fruit, the nectarine (P. persica var. nectarina (Aiton) Maxim.) with round fruit but without pubescence (fuzz), and the flat peach (P.persica var. platycarpa Bailey) with flat shape fruit (LaRue, 1989).

China is widely held to be the native land of peaches. This is supported by the presence of a wide range of wild peach types in the countryside. The peach was brought to the Mediterranean basin from Iran (formerly called Persia, which is the source of the scientific name for the peach-Prunus persica). The peach was known in Greece by $300 \mathrm{BC}$ and by the Romans shortly after $100 \mathrm{AD}$. Anatolia (Turkey) was the second main growing region and from there, it was brought to European countries.

Kazdagi Mountain located in Canakkale Province, formerly known as Ida, is the biggest mass of Biga Peninsula where the white nectarine population is concentrated at its plateaus and highlands. The region has a transition climate of Mediterranean and Aegean Sea climates which is typically mild or cool subtropical. Most of the precipitation is received during spring and winter seasons. Summer is usually dry. In this area, according to the 30 years average data of regional meteorological station, annual rainfall was $624.3 \mathrm{~mm}$, temperature was $14^{\circ}$ $\mathrm{C}$, wind speed was $1.4 \mathrm{~m} \cdot \mathrm{s}^{-1}$, relative humid-

Received for publication 13 Dec. 2004. Accepted for publication 29 Jan. 2005. We thank Ahmet Ipek and Meryem Ipek for their useful suggestions.

${ }^{2}$ To whom reprint requests should be addressed; e-mailmseker@comu.edu.tr. ity was $69 \%$, the number of frosty days was $42.8 \mathrm{~d}$, and the number of rainy days was 87 a big opportunity to grow all the deciduous fruit, grapes and vegetables.

The characterization of a genetic diversity within a population using isozymes has been done extensively due to their codominant nature (Acquaah, 1992). Bands visualized from specific enzymes represent protein products, have a genetic basis, and can provide genetic information. Isozyme polymorphisms have been used extensively for genetic diversity analysis, cultivar identification, hybrid confirmation and early screening of seedlings in fruit species including apple (Weeden and Lamb, 1985), peach (Arulsekar et al., 1986), apricot (Byrne and Littleton, 1989) and citrus (Herrero et al., 1996; Seker, 1999) due to the superiority of isozyme markers over morphological characters.

The objective of this study was to investigate some plant, fruit characteristics and isozyme polymorphisms of the native white nectarine population which is locally grown only in Canakkale Province of Turkey and compare it with common peaches and nectarine cultivars.

\section{Materials and Methods}

The highlands of Bayramic county of Canakkale were surveyed for the white nectarine population during 2002 and 2003. The area is surrounded by an irrigation dam and the area's coordinates are based on the UTM (Universal Transverse Mercator Projection) Zone 35, SpheroidWGS84 and Datum WGS84 as follows: upper right: E 462190.41-N 4412511.12, upper left: E 481792.28-N 4412541.51, lower right: E 462160.02-N d. Therefore, the climate in this region gives
4397802.11, lower left: E 481761.89-N 4397832.50. In total, 563 trees, which were grown on their own roots, were identified as fruit bearing and pest free types. Among 563 trees, 15 trees were selected for their higher yield and fruit characteristics and then they were coded with 17 (code of Canakkale in Turkey) and TBS (Tuysuz Beyaz Seftali : white nectarine) abbreviations (Table 1). Standard peach and nectarine cultivars grown widely in Canakkale were also included in this study. Some plant and fruit characteristics of trees 5 years or older of the selected 15 white nectarine genotypes, peach cultivars 'J.H. Hale', 'Red Haven', and 'Early Red', and nectarine cultivars 'Armking', 'Nectared-6', and 'Fantasia' were determined. Plant and fruit characteristics were investigated according to the protocol for distinctness, uniformity and stability tests for peach and nectarines (European Union, 2003).

Plant characteristics. Yield (kg/tree), average canopy volume $\left(\mathrm{m}^{3}\right)$ and leaf area $\left(\mathrm{cm}^{2}\right)$ were measured in selected 15 genotypes (Table $1)$. Fruit yields were presented as average of fruit yield per tree in 2002 and 2003. Average canopy volume was calculated by using canopy diameter and height of each tree. Leaf areas of selected genotypes were measured in 50 leaves per genotype using a digital planimeter.

Fruit characteristics. In 2002 and 2003, the fruit weight $(\mathrm{g})$, fruit width $(\mathrm{mm})$, fruit length $(\mathrm{mm})$, skin and flesh colors, flesh firmness $\left(\mathrm{kg} \cdot \mathrm{cm}^{-2}\right)$, stone weight $(\mathrm{g})$, total soluble solid (TSS) ( ${ }^{\circ}$ Brix), $\mathrm{pH}$, total titratable acidity (TA) $(\%)$ and flesh ratio were determined as fruit characteristics. Twenty fruit for each selected white nectarine genotype or common peach or nectarine cultivar were analyzed and the analyses were replicated three times (a total of 60 fruit from each genotype peryear). The fruit sampling was carried out during the harvesting period for each genotype, from beginning of 15 July to 15 Aug. The harvesting criterion was based on optimal skin coloration (yellow to bright yellow). The samples were transported to the pomology laboratory in wooden boxes for immediate analysis. The fruit were weighed using a balance. For measuring the flesh firmness, a hand operated penetrometer with 11.1 $\mathrm{mm}$ plunger tip (Effegi, model UO811; Italy) was used on a thin slice of skin and flesh. The skin color and flesh color were determined according to the PANTONE color catalog (Pantone Inc., 2000). The juice was obtained from each fruit group by squeezing the flesh by hand for immediate analyses. TSS and $\mathrm{pH}$ values of the juices were directly measured using a hand refractometer and a $\mathrm{pH}$ meter, respectively. TA content was measured by titrating the juice with $0.1 \mathrm{~N} \mathrm{NaOH}$ to $\mathrm{pH} 8.1$ endpoint and calculated as malic acid equivalent. All the measurements were replicated three times for each juice sample for each year. The stones from each genotype were weighed using a balance. Flesh ratio was calculated by using [(fruit weight - stone weight) / fruit weight] formula.

Statistical analysis. Statistical analysis was carried out for each characteristic except fruit yield and canopy size. Significance of varia- 


\begin{tabular}{|c|c|c|c|c|c|c|c|c|c|c|c|c|c|c|}
\hline Genotype & $\begin{array}{c}\text { Canopy } \\
\text { vol } \\
\left(\mathrm{m}^{3}\right)\end{array}$ & $\begin{array}{l}\text { Leaf } \\
\text { area } \\
\left(\mathrm{cm}^{2}\right)\end{array}$ & $\begin{array}{c}\text { Fruit } \\
\text { wt } \\
(\mathrm{g})\end{array}$ & $\begin{array}{l}\text { Fruit } \\
\text { width } \\
(\mathrm{mm})\end{array}$ & $\begin{array}{c}\text { Fruit } \\
\text { length } \\
(\mathrm{mm})\end{array}$ & $\begin{array}{l}\text { Skin } \\
\text { color }\end{array}$ & $\begin{array}{l}\text { Flesh } \\
\text { color }\end{array}$ & $\begin{array}{c}\text { Flesh } \\
\text { firmness } \\
\left(\mathrm{kg} \cdot \mathrm{cm}^{-2}\right)\end{array}$ & $\mathrm{pH}$ & $\begin{array}{c}\text { Total } \\
\text { soluble } \\
\text { solids } \\
\text { ( }{ }^{\circ} \text { Brix) }\end{array}$ & $\begin{array}{c}\text { Titratable } \\
\text { acidity } \\
(\%)\end{array}$ & $\begin{array}{c}\text { Stone } \\
\text { wt } \\
(\mathrm{g})\end{array}$ & $\begin{array}{c}\text { Flesh } \\
\text { ratio } \\
(\%)\end{array}$ & $\begin{array}{c}\text { Avg } \\
\text { fruit } \\
\text { yield }^{z} \\
(\mathrm{~kg} / \text { tree })\end{array}$ \\
\hline 17-TBS-01 & 4.7 & $39.2 \mathrm{abc}^{\mathrm{y}}$ & $55.1 \mathrm{ab}$ & $46.2 \mathrm{abc}$ & $41.5 \mathrm{a}$ & $586 \mathrm{U}$ & $100 U$ & $2.6 \mathrm{c}$ & 3.6 & $8.5 \mathrm{~d}$ & 0.5 & $5.8 \mathrm{ab}$ & 89.5 & 18.6 \\
\hline 17-TBS-02 & 6.5 & $19.7 \mathrm{~d}$ & $61.9 \mathrm{a}$ & $51.2 \mathrm{a}$ & $42.5 \mathrm{a}$ & $587 \mathrm{U}$ & $100 \mathrm{U}$ & $3.4 \mathrm{bc}$ & 3.1 & $12.7 \mathrm{abcd}$ & 0.4 & $5.9 \mathrm{ab}$ & 90.5 & 37.4 \\
\hline 17-TBS-03 & 8.9 & $26.6 \mathrm{~cd}$ & $30.6 \mathrm{c}$ & $39.0 \mathrm{c}$ & $34.1 \mathrm{bc}$ & $584 \mathrm{U}$ & $100 \mathrm{U}$ & $7.4 \mathrm{a}$ & 3.7 & $11.9 \mathrm{abcd}$ & 0.4 & $3.8 \mathrm{c}$ & 87.6 & 14.5 \\
\hline 17-TBS-04 & 8.5 & $24.3 \mathrm{~d}$ & $49.8 \mathrm{ab}$ & $45.8 \mathrm{abc}$ & $37.8 \mathrm{ab}$ & $586 \mathrm{U}$ & $100 \mathrm{U}$ & $4.1 \mathrm{bc}$ & 3.8 & $12.6 \mathrm{abcd}$ & 0.4 & $5.1 \mathrm{abc}$ & 89.8 & 24.7 \\
\hline 17-TBS-05 & 6.1 & $37.9 \mathrm{ab}$ & $43.9 \mathrm{bc}$ & $43.3 \mathrm{abc}$ & $38.8 \mathrm{ab}$ & $586 \mathrm{U}$ & $100 \mathrm{U}$ & $2.1 \mathrm{c}$ & 3.6 & $9.0 \mathrm{~cd}$ & 0.4 & $5.2 \mathrm{abc}$ & 88.2 & 35.5 \\
\hline 17-TBS-06 & 8.7 & $38.7 \mathrm{ab}$ & $54.5 \mathrm{ab}$ & $47.6 \mathrm{ab}$ & $40.2 \mathrm{ab}$ & $586 U$ & $100 \mathrm{U}$ & $5.0 \mathrm{ab}$ & 3.5 & $12.6 \mathrm{abcd}$ & 0.5 & $6.0 \mathrm{ab}$ & 89.0 & 19.1 \\
\hline 17-TBS-07 & 6.7 & $43.8 \mathrm{a}$ & $54.9 \mathrm{ab}$ & $46.0 \mathrm{abc}$ & $39.9 \mathrm{ab}$ & $586 \mathrm{U}$ & $100 \mathrm{U}$ & $3.6 \mathrm{bc}$ & 3.7 & $13.3 \mathrm{abc}$ & 0.5 & $6.1 \mathrm{ab}$ & 88.9 & 25.7 \\
\hline 17-TBS-08 & 5.0 & $21.0 \mathrm{~d}$ & $46.7 \mathrm{ab}$ & $42.5 \mathrm{bc}$ & $37.1 \mathrm{ab}$ & $586 \mathrm{U}$ & $100 \mathrm{U}$ & $2.8 \mathrm{bc}$ & 3.4 & $13.8 \mathrm{ab}$ & 0.4 & $4.8 \mathrm{bc}$ & 89.7 & 31.2 \\
\hline 17-TBS-09 & 6.8 & $37.3 \mathrm{abc}$ & $47.6 \mathrm{ab}$ & $44.4 \mathrm{abc}$ & $38.4 \mathrm{ab}$ & $586 \mathrm{U}$ & $100 \mathrm{U}$ & $3.0 \mathrm{bc}$ & 3.3 & $9.7 \mathrm{bcd}$ & 0.5 & $5.3 \mathrm{abc}$ & 88.9 & 24.9 \\
\hline 17-TBS-10 & 6.1 & $41.2 \mathrm{a}$ & $58.0 \mathrm{ab}$ & $47.6 \mathrm{ab}$ & $40.2 \mathrm{ab}$ & $586 \mathrm{U}$ & $100 U$ & $4.0 \mathrm{bc}$ & 3.5 & $14.4 \mathrm{a}$ & 0.4 & $6.6 \mathrm{a}$ & 88.6 & 28.9 \\
\hline 17-TBS-11 & 8.5 & $28.4 \mathrm{bcd}$ & $50.6 \mathrm{ab}$ & $45.6 \mathrm{abc}$ & $38.0 \mathrm{ab}$ & $587 \mathrm{U}$ & $100 \mathrm{U}$ & $4.2 \mathrm{bc}$ & 3.8 & $12.1 \mathrm{abcd}$ & 0.4 & $5.0 \mathrm{bc}$ & 90.1 & 19.4 \\
\hline 17-TBS-12 & 5.4 & $23.6 \mathrm{~d}$ & $50.3 \mathrm{ab}$ & $45.4 \mathrm{abc}$ & $38.0 \mathrm{ab}$ & $587 \mathrm{U}$ & $100 \mathrm{U}$ & $3.9 \mathrm{bc}$ & 3.5 & $12.3 \mathrm{abcd}$ & 0.4 & $5.2 \mathrm{abc}$ & 89.7 & 14.5 \\
\hline 17-TBS-13 & 4.2 & $36.2 \mathrm{abc}$ & $45.7 \mathrm{bc}$ & $48.8 \mathrm{ab}$ & $26.8 \mathrm{c}$ & $583 \mathrm{U}$ & $100 \mathrm{U}$ & $7.1 \mathrm{a}$ & 3.6 & $12.1 \mathrm{abcd}$ & 0.5 & $5.1 \mathrm{abc}$ & 88.8 & 25.9 \\
\hline 17-TBS-14 & 4.9 & $42.2 \mathrm{a}$ & $51.9 \mathrm{ab}$ & $46.3 \mathrm{abc}$ & $38.2 \mathrm{ab}$ & $586 U$ & $100 U$ & $4.2 \mathrm{bc}$ & 3.4 & $13.5 \mathrm{abc}$ & 0.5 & $5.5 \mathrm{ab}$ & 89.4 & 19.6 \\
\hline 17-TBS-15 & 5.7 & $28.1 \mathrm{bcd}$ & $47.3 \mathrm{ab}$ & $44.8 \mathrm{abc}$ & $37.2 \mathrm{ab}$ & $587 \mathrm{U}$ & $100 \mathrm{U}$ & $3.8 \mathrm{bc}$ & 3.9 & $12.6 \mathrm{abcd}$ & 0.4 & $4.9 \mathrm{bc}$ & 89.6 & 21.0 \\
\hline Average & 6.4 & 32.5 & 49.9 & 45.7 & 37.9 & --- & --- & 4.1 & 3.5 & 12.1 & 0.4 & 5.4 & 89.2 & 24.0 \\
\hline Significance & --- & $*$ & $* *$ & $* *$ & $* *$ & NS & NS & $* *$ & NS & $* *$ & NS & $* *$ & NS & --- \\
\hline
\end{tabular}

${ }^{\mathrm{z} A v e r a g e ~ v a l u e ~ o f ~} 2002$ and 2003 harvesting years.

y Means within a column followed by the same letter are not significantly different at the $P \leq 0.05$ level.

NSNonsignificant.

tion among the selected genotypes and peach and nectarine cultivars was determined from analysis of variance by using SAS Statistical Analysis software. Analysis of variance was computed using the General Linear Model (GLM) procedure of SAS with mean separation using protected LSD (SAS Institute, 1998).

Isozyme analysis. Sixty genotypes including 15 selected genotypes whose plant and fruit characteristics were determined were used for isozyme analysis to represent broader genetic variation within this white nectarine population. Isozyme profiles of these six enzymes below were also determined for eight peach cultivars ('J.H. Hale', 'Red Haven', 'Early Red', 'Morettini', 'Dixired', 'Starking Delicious', 'Mary Gold', and 'Early Hale') and four nectarine cultivars ('Fantasia', 'Armking', 'Nectared-4', and 'Nectared-6').

Isozyme variation was surveyed for six enzymes including malate dehydrogenase $(\mathrm{MDH}$, EC 1.11.1.37), isocitrate dehydrogenase (IDH, EC 1.1.1.42), alcohol dehydrogenase (ADH, EC 1.1.1), peroxidase (PRX, EC 1.11.1.7), phosphogluco isomerase (PGI, EC 5.3.1.9), and phosphogluco mutase (PGM, EC 2.7.5.1).

Extracts were prepared by homogenization of $50 \mathrm{mg}$ fresh young leaves according to the method described by Arulsekar and Parfitt (1986). Extraction method, gel conditions and staining procedures were described in Arulsekar and Parfitt (1986) and Seker (1999).

In the electrophoretic study, each tree was taken as a genotype, isozyme pattern was called as zymogram, each isozyme locus was named as gene and each band was considered as an allele on the locus according to its fast or slow electrophoretic migration. Alleles were designated from fastest to slowest migration level as F (most anodal), I (faster migrating than $\mathrm{M}$ ), $\mathrm{M}$ (slower migrating than I), or $\mathrm{S}$ (slowest migrating allele or most cathodal) according to Torres et al. (1982).

\section{Results and Discussion}

The origin of this white nectarine population is unknown and there is no reference indicating that similar peaches or nectarines are grown in other Middle East and South Asia districts to our knowledge. The population has been enlarged by local growers due to its high market value and high consumer acceptance. Currently, the diversity within the white nectarine population has been increased due to the use of seedlings to repropagate white nectarines by growers. Growers prefer using seedlings to repropagate white nectarine instead of grafting on rootstocks because of its relatively short juvenile period (2 years) and easiness of repropagation by seedlings. The other reasons could be the lack of stan- dard rootstocks recommended for the white nectarines and the absences of standard white nectarine cultivars as a scion source.

Plant characteristics. Economical life span of the white nectarine trees is about 10 to 15 years on their own roots under cultivation and they are relatively short lived compared to peach trees, which can live about 20 to 25 years at the same location (Yilmaz, 2004). The white nectarines have the similar pest and disease profile as peaches, therefore growers use same pest control as we observed. The tree characteristics of native white nectarines are similar to common peach and nectarine trees in terms of canopy shape, shoot, leaf and flower structures (M. Seker, data not presented). The variation for canopy volume among the 15 selected white nectarine genotypes was not significant (Table 1 ) and the white nectarines with average of 6.4 $\mathrm{m}^{3}$ had the smallest canopy volume compared to the common peaches and nectarines (Table 2 ), suggesting that white nectarine has smaller trees than that of common peach and nectarine cultivars. However, pruning and training methods or grafting can affect the tree size significantly. Peaches and nectarines are usually grafted on peach seedlings in the region while white nectarines have been grown on its own roots. On the other hand, peaches, nectarines or white nectarines are not treated differently by growers in terms of pruning or training. In

Table 2. Some plant and fruit characteristics of selected white nectarine genotypes, standard peach and nectarine cultivars.

\begin{tabular}{|c|c|c|c|c|c|c|c|c|c|c|}
\hline $\begin{array}{l}\text { TBS avg } \\
\text { and } \\
\text { common } \\
\text { cultivars }\end{array}$ & $\begin{array}{c}\text { Canopy } \\
\text { vol } \\
\left(\mathrm{m}^{3}\right)\end{array}$ & $\begin{array}{l}\text { Leaf } \\
\text { area } \\
\left(\mathrm{cm}^{2}\right)\end{array}$ & $\begin{array}{c}\text { Fruit } \\
\text { wt } \\
(\mathrm{g})\end{array}$ & $\begin{array}{l}\text { Fruit } \\
\text { width } \\
(\mathrm{mm})\end{array}$ & $\begin{array}{l}\text { Fruit } \\
\text { length } \\
(\mathrm{mm})\end{array}$ & $\begin{array}{c}\text { Flesh } \\
\text { firmness } \\
\left(\mathrm{kg} \cdot \mathrm{cm}^{-2}\right)\end{array}$ & $\begin{array}{c}\text { Total } \\
\text { soluble } \\
\text { solids } \\
\left.\text { ( }{ }^{\circ} \text { Brix }\right)\end{array}$ & $\begin{array}{c}\text { Titratable } \\
\text { acidity } \\
(\%)\end{array}$ & $\begin{array}{c}\text { Stone } \\
\text { wt } \\
(\mathrm{g})\end{array}$ & $\begin{array}{c}\text { Flesh } \\
\text { ratio } \\
(\%)\end{array}$ \\
\hline TBS & $6.4 b^{z}$ & 32.5 & $49.9 \mathrm{~d}$ & $45.7 \mathrm{~b}$ & $37.9 \mathrm{~b}$ & $4.1 \mathrm{a}$ & 12.1 & 0.4 & $5.4 \mathrm{~b}$ & $89.2 \mathrm{~b}$ \\
\hline J.H. Hale & $11.5 \mathrm{a}$ & 44.0 & $185.1 \mathrm{a}$ & $70.2 \mathrm{a}$ & $69.6 \mathrm{a}$ & $2.5 \mathrm{~b}$ & 14.7 & 0.3 & $8.1 \mathrm{a}$ & $95.6 \mathrm{a}$ \\
\hline Red Haven & $9.7 \mathrm{ab}$ & 48.8 & $169.0 \mathrm{ab}$ & $67.8 \mathrm{a}$ & $66.8 \mathrm{a}$ & $3.2 \mathrm{ab}$ & 13.5 & 0.4 & $8.6 \mathrm{a}$ & $94.9 \mathrm{a}$ \\
\hline Early Red & $8.4 \mathrm{ab}$ & 36.0 & $145.8 \mathrm{bc}$ & $67.1 \mathrm{a}$ & $58.4 \mathrm{a}$ & $4.2 \mathrm{a}$ & 10.7 & 0.5 & $8.0 \mathrm{a}$ & $94.5 \mathrm{a}$ \\
\hline Armking & $12.5 \mathrm{a}$ & 43.8 & $132.6 \mathrm{c}$ & $61.5 \mathrm{a}$ & $62.1 \mathrm{a}$ & $3.2 \mathrm{ab}$ & 15.2 & 0.4 & $7.8 \mathrm{a}$ & $94.1 \mathrm{a}$ \\
\hline Nectared-6 & $10.8 \mathrm{ab}$ & 47.8 & $145.9 \mathrm{bc}$ & $68.2 \mathrm{a}$ & $65.3 \mathrm{a}$ & $2.4 \mathrm{~b}$ & 12.3 & 0.4 & $8.9 \mathrm{a}$ & $93.9 \mathrm{a}$ \\
\hline Fantasia & $11.2 \mathrm{a}$ & 37.8 & $177.5 \mathrm{a}$ & $69.2 \mathrm{a}$ & $68.3 \mathrm{a}$ & $2.4 \mathrm{~b}$ & 13.8 & 0.4 & $9.5 \mathrm{a}$ & $94.6 \mathrm{a}$ \\
\hline Significance & $*$ & NS & $* *$ & $* *$ & $* *$ & $*$ & NS & NS & $* *$ & $*$ \\
\hline
\end{tabular}

${ }^{\mathrm{z}}$ Means within a column followed by the same letter are not significantly different at the $P \leq 0.05$ level

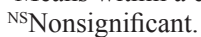




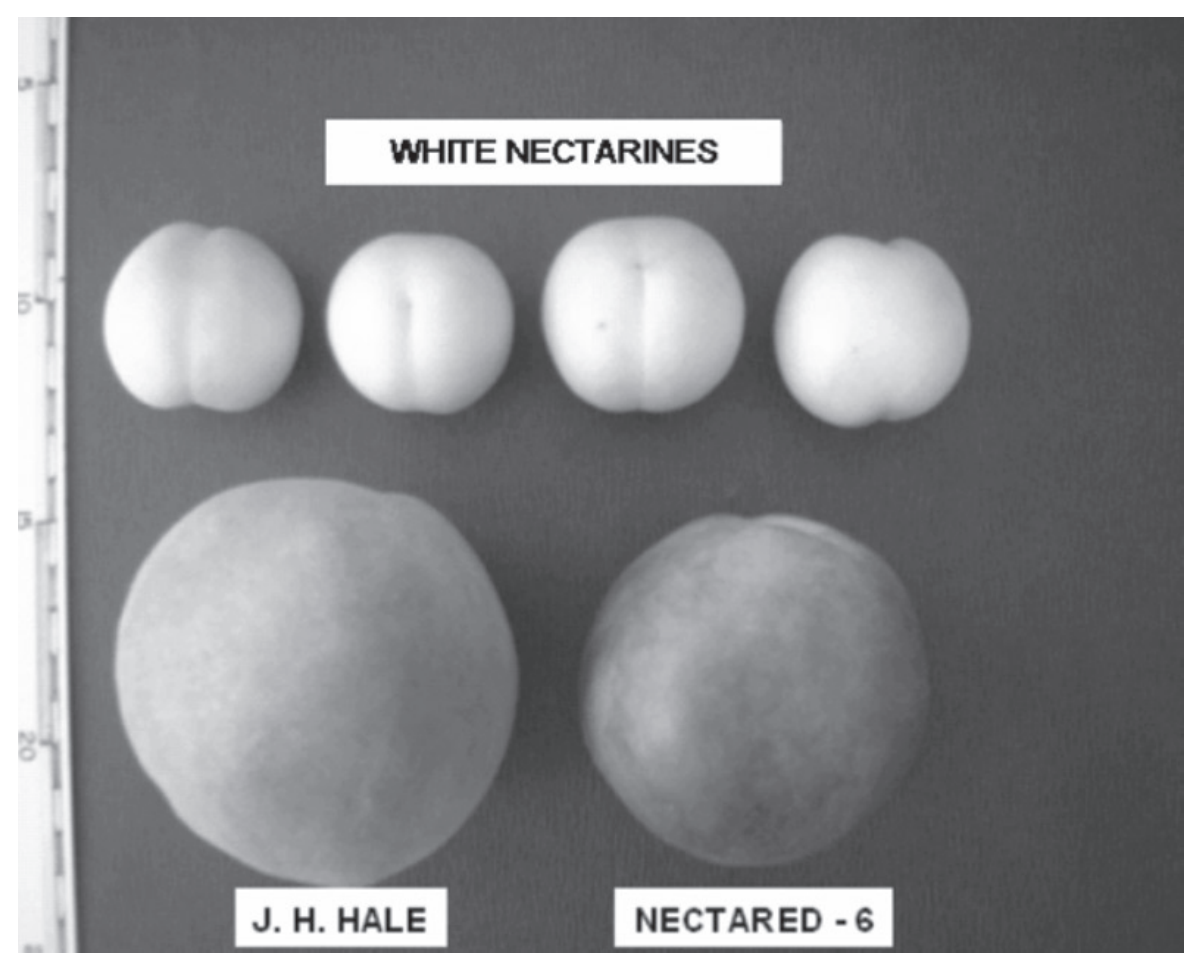

Fig. 1. Comparison of 'J.H. Hale' peach, 'Nectared-6' nectarine, and white nectarine fruit.

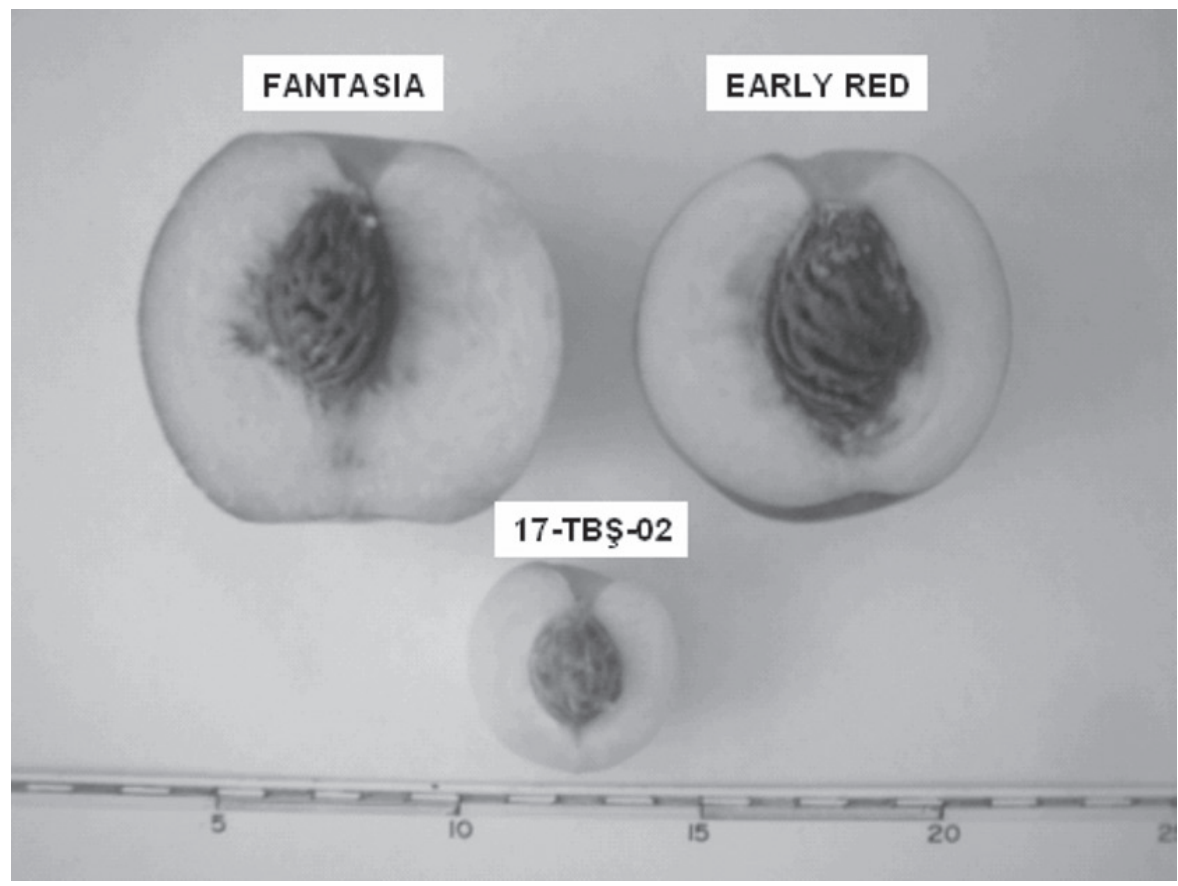

Fig. 2. Internal picture of the fruit of 'Early Red' peach, 'Fantasia' nectarine, and '17-TBS-02' white nectarine for comparison.

this case, it is not expected to have differences in tree size unless peaches, nectarines or white nectarines are genetically different.

White nectarines have simple leaves and lanceolate in shape which is similar to the leaves of peaches or white nectarines. A significant variation were observed for leaf area among the selected white nectarine genotypes which ranged from 19.7 to $43.8 \mathrm{~cm}^{2}$ (Table 1), but their average leaf area, $32.5 \mathrm{~cm}^{2}$ was not different from common peach or nectarine
Fruit are harvested from mid-July to the end of September, which is close to picking time of peach cultivars 'Glohaven', 'Cresthaven', and 'J.H.Hale' and nectarine cultivars, 'Nectared4', 'Nectared-6', and 'Fantasia'. Defoliation occurs from November to December then followed by a period of dormancy. The white nectarine trees have a regular fruit bearing habit like other peaches and nectarines based on our observations over 5 years (M. Seker, data not presented). The fruit yields of the 15 selected genotypes ranged from 37.4 to $14.5 \mathrm{~kg} /$ tree with the average of $24.0 \mathrm{~kg} /$ tree (Table 1).

Fruit characteristics. The fruit of white nectarines have fuzzless, shiny skin similar to those of nectarines (Figs. 1 and 2). Nectarines are described as fuzzless peach, because the difference between the two fruit types is due to a single recessive gene (LaRue, 1989). The fruit shape of white nectarines is oblate to round and symmetric. The size, color and flesh characteristics of white nectarine fruit differ from common peaches and nectarines (Table 2; Figs. 1 and 2). The fruit weights significantly changed among selected white nectarine genotypes and ranged from $30.6 \mathrm{~g}$ to $61.9 \mathrm{~g}$, with the average of $49.9 \mathrm{~g}$ (Table 1). On the other hand, the average fruit weight ranged from $90 \mathrm{~g}$ for 'Springtime' and 'Royal Gold' to $280 \mathrm{~g}$ for 'J.H. Hale' and 'Fowler' in common peaches and from $90 \mathrm{~g}$ in 'Mayred' and 'June Grand' to $170 \mathrm{~g}$ for 'Rhone Gold', 'Fire Gold', 'Stark Red Gold', and 'Nectared-6' in common nectarine cultivars grown in Turkey (Kaska et al., 1992; Kuden et al., 1995; Ozcagiran et al. 2003). Our findings of fruit weights for peach and nectarine cultivars in the same region ranged from $132.6 \mathrm{~g}$ for 'Armking' to 185.1 $\mathrm{g}$ for 'J.H. Hale'. These results indicated that the fruit weight of white nectarine is significantly smaller than that of common peaches and nectarines (Table 2).

Although the skin color of white nectarines differs slightly among 15 selected trees, it was generally bright cream at ripening $(586 \mathrm{U}, 587 \mathrm{U})$ (Table 1). On the other hand, the skin color of common peach and nectarine cultivars grown in the same region ranges from rich yellow to reddish brown. The flesh color of all white nectarines was white-cream (100U) (Table 1) and no anthocyanin coloration was observed under skin, in flesh, or around stone unlike some peach and nectarine cultivars. Flesh texture is not fibrous and its firmness can be considered as medium to firm since it was varied significantly among selected white nectarine genotypes(Table 1) and its firmness is similar to firm peach or nectarine cultivars (Table 2).

Total soluble solid content is considered as a good parameter for determining the fruit quality of peaches and nectarines. TSS content and total titratable acidy of white nectarine were similar to common peach and nectarine cultivars grown in Turkey (Table 2), although there was a significant variation among the selected white nectarine genotypes for TSS, which ranged from 8.5 to $14.4^{\circ}$ Brix (Table 1).

From round to obviate stones of white nectarines with small pits on the relief of stone surface are similar to shape of other peach and nectarine cultivars and the white nectarines had 

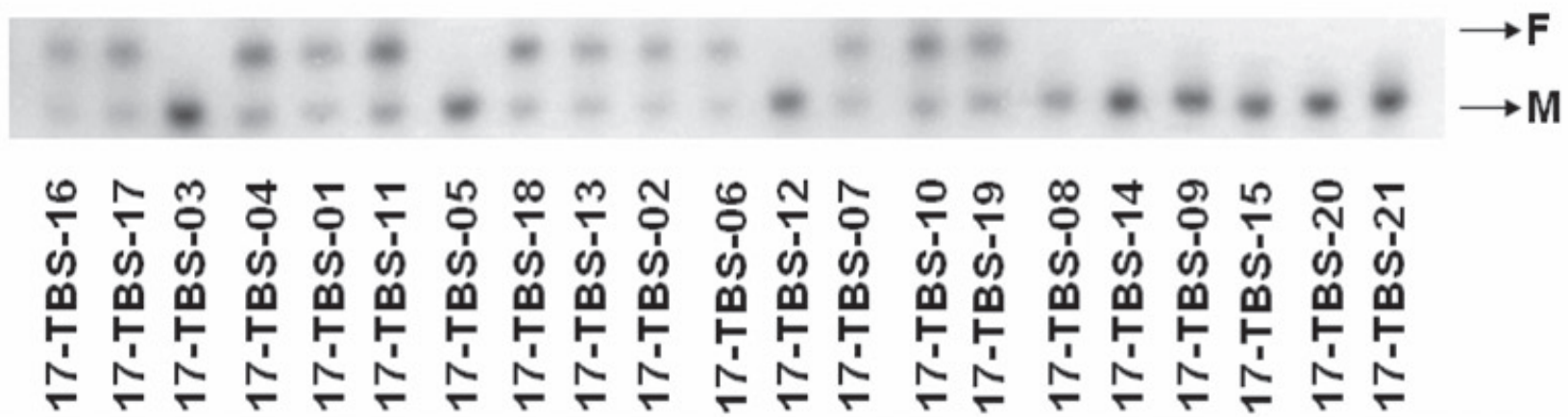

Fig. 3. Isozyme profiles of IDH in some white nectarine genotypes.

Table 3. Allelic constitution of six enzyme systems in some white nectarine genotypes and some peach and nectarine cultivars.

\begin{tabular}{|c|c|c|c|c|c|c|c|c|c|}
\hline \multicolumn{8}{|c|}{ Enzyme locus } & \multirow{2}{*}{$\begin{array}{l}\text { Genotypes } \\
\text { (no.) }\end{array}$} & \multirow{2}{*}{$\begin{array}{l}\text { Selected white nectarine trees, } \\
\text { standard peaches and nectarines }\end{array}$} \\
\hline$\overline{\mathrm{MDH}}$ & $1 \mathrm{MDH}-2$ & IDH & $\mathrm{ADH}$ & PRX & PGI & PGM-1 & PGM-2 & & \\
\hline IS & FI & MM & MM & II & MM & MS & $\mathrm{FF}$ & 13 & 17-TBS-08, 17-TBS-09, 17-TBS-14 \\
\hline MS & FS & MM & MM & II & MM & MS & FF & 5 & 17-TBS- 03 \\
\hline MS & FM & FM & MM & MM & IM & MS & $\mathrm{FF}$ & 9 & $\begin{array}{l}\text { J.H. Hale, Red Haven, Early Red, Morettini, Dixired, Armking, } \\
\text { Starking Delicious, Mary Gold, Early Hale }\end{array}$ \\
\hline
\end{tabular}

${ }^{2 \mathrm{~F}}=$ fast migrating band; $\mathrm{I}=$ intermediate (faster than $\mathrm{M}$ ) migrating band; $\mathrm{M}=$ medium (slower than $\mathrm{I}$ ) migrating band; $\mathrm{S}=$ slow migrating band.

the smallest stone $(5.4 \mathrm{~g})$ compared to the other peach and nectarine cultivars grown in Turkey (Table 2) and variation among selected white nectarine genotypes was not significant (Table 1). The flesh of semi-cling fruit was clung to the stone at the soft ripe, making white nectarines clingstones. In terms of flesh ratio, there was no significant difference among the selected white nectarine genotypes (Table 1). However, white nectarines had the smallest flesh ratio, $89.2 \%$ compared to the other common peach and nectarine cultivars, indicating that each fruit of white nectarines has less flesh than common peach and nectarine cultivars (Table 2; Fig. 2).

Isozyme polymorphisms. Six enzyme systems-ADH, PRX, MDH, IDH, PGI, and PGM - had activity in white nectarine population resulting clear bands. Although ADH and PRX were monomorphic with two alleles in each enzyme system, MDH, IDH, PGI, and PGM zymograms had polymorphic alleles among the 60 surveyed white nectarine genotypes (Fig. 3 ), indicating the presence of genetic variation within the white nectarine population. Based on polymorphic isozyme alleles of MDH, IDH, PGI, and PGM, these white nectarine genotypes were placed into four electrophoretic groups (Table 3). On the other hand, peach and nectarine cultivars analyzed with these six enzyme systems were clustered into two electrophoretic groups. While one group included all peach cultivars and one nectarine cultivar, the other group contained only three nectarine cultivars (Table 3). Although PRX was not polymorphic within the population of white nectarine, it had two alleles different from peach cultivars and one allele different from nectarine cultivars (Table 3). Similarly, PGI has one allele (F) different from peaches and nectarines in most of white nectarine genotypes (Fig. 4). These results demonstrated that white nectarine population were genetically different from standard peach and nectarine cultivars analyzed suggesting that it could be a novel nectarine type.

Isozymes for characterizing genetic variations in Prunus species have been reported to be one of the most useful marker systems due to their high level of polymorphisms (Agarwal et al., 2001; Arulsekar and Parfitt 1986; Byrne and Littleton, 1989; Chaparro et al., 1987). Agarwal et al. (2001) reported that variation exists in four enzyme systems, peroxidase, isocitrate dehydrogenase, acid phosphatase and alkaline phosphatase among 12 peach cultivars. PGM has been reported to be a monomeric enzyme with polymorphisms in two loci in Prunus (Byrne and Littleton, 1989; Chaparro et al., 1987). Under present conditions, PGM isozymes showed activity in two zones of the gel called PGM-1 and PGM-2 loci similar to previous researches but only one of them showed variation (Table 3 ).

\section{Conclusions}

Our results demonstrated that the white nectarines have similar tree characteristics to peach or nectarine cultivars. Whereas, their fruit characteristics were different from common peach or nectarine cultivars and white nectarines with small fruit size and low flesh ratio are less attractive than common peach and nectarine cultivars. However, they receive higher market value than common nectarines and peaches due to its unique flavor. Individuals testing white nectarines identified them as either plum or apricot fruit because of its distinct flavor from common peaches or nectarines. In addition, isozyme analysis indicated that the white nectarines are genetically different from the other peaches and nectarines. Based on these observations, we believe that white nectarines could be originated from a hybrid seedling between nectarine and another Prunus species. Further studies will be performed to determine the origin of white nectarines by using molecular markers such as RAPD (randomly amplified polymorphic DNA), AFLP (amplified fragment length polymorphims), SSR (simple sequence repeats) and GISH (genomic in-situ hybridization) analysis. In addition, chromosome number, genome size and ploidy level will be determined by using

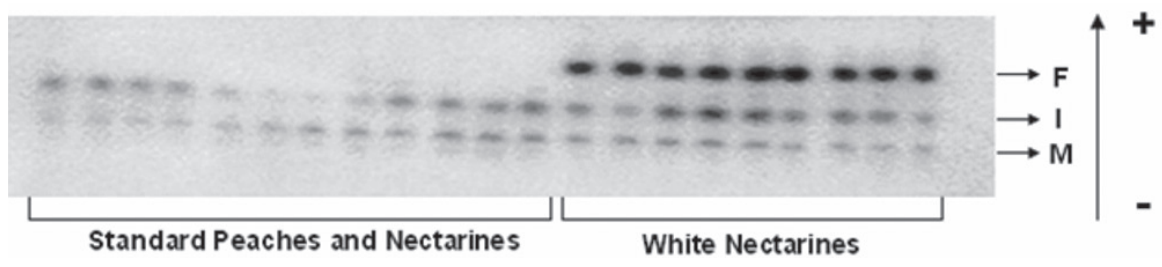

Fig. 4. Isozyme profiles of PGI in some standard peach and nectarine cultivars and some white nectarine genotypes. 
cytological analysis.

To our knowledge, no standard cultivar of this novel white nectarine has been described. Future studies should also include breeding for standard white nectarine cultivars with better appearance to increase its attractiveness while keeping its unique flavor and the variation in this population will be very useful for selecting standard white nectarine cultivars. In addition, the white nectarine population can also represent a novel source of breeding materials for improvement of peaches or nectarines.

\section{Literature Cited}

Acquaah, G. 1992. Practical protein electrophoresis for genetic research. (Dioscorides Press, Portland, Ore.).

Agarwal, S., A.K. Nath, and D.R. Sharma. 2001. Characterisation of peach (Prunus persica L.) cultivars using isozymes as molecular markers. Scientia Hort. 90:227-242.

Arulsekar, S. and D.E. Parfitt. 1986. Isozyme analysis procedures for stone fruit, almond, grape, walnut, pistachio and fig. HortScience 2:928-933.

Arulsekar, S., D.E., Parfitt, W. Beres, and P.E. Han- sche. 1986. Genetics of malate dehydrogenase isozymes in the peach. J. Hered. 77:49-51.

Byrne, D.H. and T.G. Littleton. 1989. Characterization of isozyme variability in apricots. J. Amer. Soc. Hort. Sci. 114:674-678.

Chaparro, J.X., R.E. Durham, G.A. Moore, and W.B Sherman. 1987. Use of isozyme techniques to identify peach X 'Nonpareil' almond hybrids. HortScience 22:300-302.

European Union. 2003. Protocol for distinctness, uniformity and stability tests for peach and Nectarines. European Union, Community Plant Variety Office, CPVO-TP/53/1. 24 p.

Herrero, R., M.J. Asisns, E.A. Carbonell, and L. Navarro. 1996. Genetic diversity in the orange subfamily Aurantioideae. I. Intraspecies and intragenus genetic variability. Theor. Appl. Genet. 92:599-609.

Kaska, N., M. Saglamer, M. Gungor, and H. Ayanoglu. 1992. Adaptation of peach cultivars for Mediterranean region of Turkey. 1st Natl. Congr. Hort., 13-16 Oct. 1992. Izmir, Turkey. 1:487-490.

Kuden, A. B., F. Ozmetli, N. Kaska, and A. Kuden. 1995. Fruit yield and quality characteristics of new peach and nectarine cultivars. 2nd Natl. Congr. Hort., 3-6 Oct. 1995. Adana, Turkey.
1:479-482.

LaRue, J.H. 1989. Introduction. In: H.H. LaRue and R.S. Johnson (eds.). Peaches, plums, and nectarines, p. 1-2. Univ. Calif., Oakland.

Ozcagiran, R., A. Unal, E. Ozeker, and M. Isfendiyaroglu. 2003. Temperate zone fruit: Stone fruit, Univ. Ege, Izmir, Turkey.

Pantone Inc., 2000. Pantone color specifier. Pantone, Inc., Carlstadt, N.J.

SAS Institute. 1998. SAS/STAT guide for personal computers. SAS Inst. Inc., Cary, N.C.

Seker, M. 1999. The characterization of important citrus genotypes and relatives in Aurantioideae sub-family by relative genome sizes and different isozyme systems. PhD. diss. (in Turkish with English summary). Univ. Cukurova, Adana, Turkey.

Torres, A.M., R.K. Soost, and T. Mau-Lastovicka. 1982. Citrus isozymes, genetics and distinguishing nucellar from zygotic seedlings. J. Hered. 73:335-339.

Weeden, N.F. and R.C. Lamb. 1985. Identification of apple cultivars by isozyme phenotypes. J. Amer. Soc. Hort. Sci. 10:509-515.

Yilmaz,A. 2004. Comparison of white nectarine trees with common peach and nectarine cultivars. MSc diss. (in Turkish with English summary). Univ Canakkale Onsekiz Mart, Canakkale, Turkey. 